\title{
SYMPTOMS VERSUS PROBLEMS (SVP) FRAMEWORK ON EXPORT BARRIERS TO SME'S LED ELECTRONIC PRODUCTS IN TAIWAN
}

\author{
Noor N. KADER ALI ${ }^{1}$ and Indra PERUMAL ${ }^{2}$ \\ ${ }^{1 \& 2}$ Graduate School of Business, Universiti Sains Malaysia, 11800 Penang, Malaysia. \\ nnasir@usm.my Author \\ me indra89@yahoo.com
}

\begin{abstract}
Export barriers are a common constraints to SMEs when exporting goods. In 2013, Taiwan's export sales dropped by $18.5 \%$ due to SMEs' difficulty to explore the overseas market, thus, redirect their sales locally. The objective of this case study is to identify the internal and external barriers, and the export model practiced by one export case in Taipei, Taiwan. Findings via semi-structured interviews, field observation and analysis of unpublished company data are summarized using a new root-cause analysis tool called Symptoms versus Problems (SVP) framework for SME LED Exports. The new SVP framework discovers many symptoms leading to recognition of six major problems, namely, high operational cost, poor marketing strategy, lack of cash flow funds, talent and skill sets, government support, and too many foreign bureaucracy regulations. These problems are categorized into three groups, namely, operation, marketing and government bureaucracies. The recommendations for each problem are structured to improve product costs, branding and advertisement strategies, cash flow management, technical know-how of foreign market behaviour, sources of information and network, and managing the foreign bureaucracies. Interestingly, this study discovers another new framework that overcome LED export barriers called "House of Pillars for LED Exports" in Taiwan.
\end{abstract}

Keywords: Export Barriers; Foreign Market Behaviour; House of Pillars for LED Exports; LED Electronics; SME Exports; Symptoms versus Problems (SVP) Framework; Strategic Decision Making;

\section{INTRODUCTION}

Export barriers are one of the main constraints faced by small and medium enterprises (SMEs) when exporting goods or services across the nations. In Asian countries, $98 \%$ of the enterprises are SME, contributing 66\% to the nation's average employment from 2007 to 2012. (Asian Development Bank, 2013). In Taiwan, nearly 97.6\% of total establishments consist of small and medium enterprise (SME), accounted approximately 1.33 million establishments in 2013. Nevertheless, majority of Taiwan's share of export sales are dominated by large corporation accounting to $85.5 \%$, while SME share of export sales is only $14.4 \%$ in 2013. (ROC Yearbook, 2014). 


\section{PROBLEM STATEMENT}

Export barriers are often the cause of many firms' failures in foreign business operations, bringing financial losses and negative attitudes toward international activities among exporters (Leonidou, 1995). Despite the total number of SMEs increased by $1.87 \%$ or 24,453 establishment in 2013, domestic sales for SME increased by $2.74 \%$ growth rate from 2012 to 2013, Taiwan encountered a dropped in SME export sales by $18.5 \%$ from NT $\$ 1,748,080$ (2012) to NT\$1424,225 (2013), (ROC Yearbook, 2014). Thus, affecting the contribution to national GDP. Difficulties to explore the overseas market forces Taiwanese SMEs to redirect their sales domestically avoiding international business risks. Some SMEs engaged in indirect exporting through international intermediaries (Armstrong \& Kotler, 2009). Most of the Taiwanese SMEs depend on China as a manufacturing base to benefit from lower manufacturing cost (Hao, 2014). Generally, SMEs faced two types of export barriers, namely, internal and external export barriers. Internal barriers consist of knowledge, information, human, logistic and network barrier, production barrier, monetary/capital, financial, pricing, organisational, and marketing and products (Morgan \& Katsikeas, 1997; Leonidou, 2000; Shaw \& Darroch, 2004; Tesfom \& Lutz 2006; Milanzi, 2012). External barriers comprise of macroeconomic, societal and cultural, competitor, tariff, government regulatory and procedural barrier (Silva and Rocha,2001; Leonidou, 2004; Julien \& Ahmed et al 2004; Tesfom \& Lutz 2006; Altintas et al, 2007; Rutihinda 2008; Kahiya 2013). Thus, the objective of this case study is to identify the internal and external barriers, and also, to discover the strengths and weaknesses of the business model used, that hinder one SME export case in Taipei, Taiwan, causing slow growth in export performance.

\section{METHODOLOGY}

The sequential qualitative methodology in this research begins with semi structured interviews and field observation, followed by analysis of unpublished and published secondary data whereby the findings are summarized in a root-cause analysis tool called Symptoms Versus Problems (SVP) framework (Kader Ali, et.al, 2014 \& 2015), that tracks the causes of the symptoms and problems in a newly designed framework for SME exports. As such, it provides appropriate solutions, value add to the company, and the discovery of another new framework called House of Pillars of SME exports.

\section{CASE FINDINGS}

The SME analysed in this study produces LED filament bulb and other general LED lighting by using high innovation and technology methods which are more expensive than its competitors in Taiwan and China. It's a hurdle to the company's growth in recent years, making it unstable to expand internationally. The internal barriers consist of barriers in knowledge and information, human resources, production, monetary capital investment, financial structure, pricing, marketing, and product offering. The external barriers include government regulatory, industry forces, market forces, and macroeconomic factors. These 
barriers caused the SME to decrease in export sales, growth and performance in past few years.

The company focuses on research and development (R\&D) of the LED light bulb and system lighting in the field of the general lighting, with 10 staffs located in Taipei, Taiwan, while 50 workers are employed in the manufacturing facilities located in Mainland China.

\section{Vision and Mission}

The company's vision is to be the world best lightbulbs manufacturer, while, the mission is to be best global LED lighting innovator, providing most optimal and top quality solutions in lighting through continuous improvement in lighting industry.

\section{Strategic Direction}

The strategic direction can be divided into three main categories, namely, company development; technology and innovation; as well as, investors and export market. The company sells light bulb for indoor and outdoor lighting usage, such as Vintage bulb, AC Led Bulb for street lighting, household lighting, commercial lighting and outdoor lighting field. Meanwhile, the company website is not effective in generating sales as evidenced in the financial reports. While the products are distributed locally to supermarkets and hardware stores, the main focus are to manufacture to order, and export to its partners in Australia, Singapore, India, France, United Kingdom, Germany, Switzerland and United States. The reason for high demand from Europe is due to price competitiveness, and the high cost of utility consumption in Europe. The CEO mentioned that the company's largest export market is Germany. Thus, this company focus its exports to Europe market largely, and less focus on domestic or other Asian market.

\section{Business Model and Its Challenges}

Interviews with the CEO revealed the company uses a "classical business model" normally adopted by many Taiwanese SMEs in export business. According to the CEO, the company secures most of its clients when participating in LED lighting exhibitions in China, Hong Kong, Taiwan and other foreign countries. For example, the company promotes their product brand in Guangzhou International Lighting Exhibition, China (2012) and Lighting Fair in Hong Kong (2013), and other exhibitions in Taiwan to capture latest market trend. LED lighting exhibition became the platform for LED SMEs to expand their business network.

The challenge in the negotiation process is to agree on the terms of contract which include description on goods, quantity, price, trade terms, time of shipment, inspection, certificate of origin (MATRADE, 2003). The biggest challenge for this company is to overcome the respective governmental regulatory requirements and bureaucracies. Additionally, this SME is required to provide prototypes approved by the clients before signing of the contract agreement, in comparison to large LED manufacturers where clients have to follow the large manufacturers' terms of negotiation. Nevertheless, the manager point out that the most important consideration by German buyers, specifically, is the concern for quality, efficiency, durability, reliability and on time delivery of the LED lightbulb offered. 


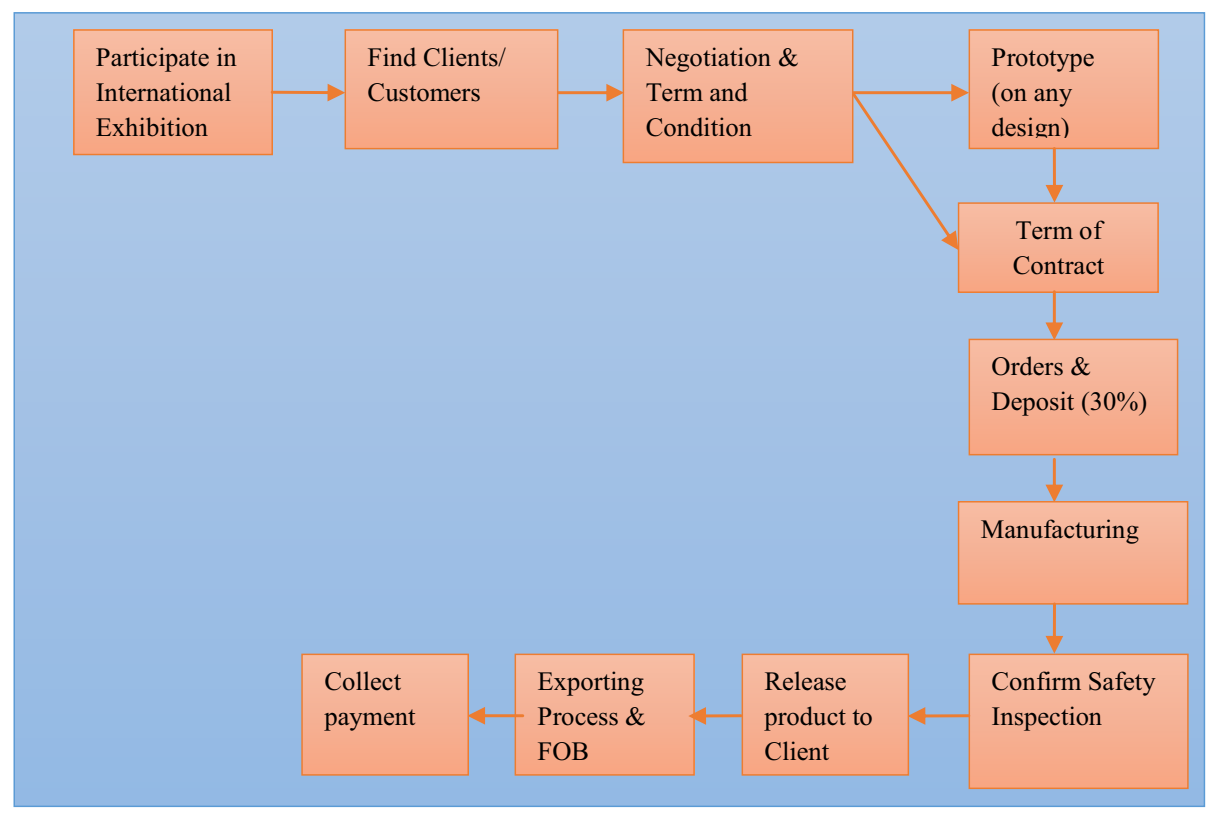

Figure 1: The Company's Business Model for Exports

Collection of $30 \%$ deposit from the total cost is a risk sharing concept between the company and its customers. The exporter test products for inspection including all legal and safety compliances of the international safety standard such as ROHS, CE Mark, and $\mathrm{REACH}$. The strict foreign regulatory requirements on product safety, consequently increases exporter's operational costs to qualify the foreign safety certificates.

The logistic costs for export depend on the mode of transportation method and effective schedules of truckload freight, ocean and air freight. There are delays on freight schedules that incur higher freight costs. Furthermore, the company practices a free on board (FOB) shipping method with distributors from Germany, Australia, Macau and others, where the buyer bears all costs and risks of loss or damage of the goods from port of shipment (MATRADE, 2003). Previously, there were many cases reported on defect or damaged Lightbulbs. A replacement cost added to total distribution costs.

Once the products were delivered to foreign market, the company/exporter will receive payment without using a documentary bill. The company uses a simplest and fastest way of collecting payment through bank services called "wire transfer" or telegraphic transfer. The company does not use any other third party online payment services. 


\section{CASE ANALYSIS \& DISCUSSION}

\section{Symptoms versus Problems (SVP) Framework}

The interview with the CEO revealed that Taiwanese SMEs began as a family business as ODM/OEM for local consumption and later expand to export markets. The slow growth of this SME in export market is due to internal and external barriers (The Company, 2015). The SVP Framework is adapted from Kader Ali, et.al $(2014,2015)$. The construct of "SVP for SME LED Exports" is a new framework developed in this study for easy understanding of practitioners to differentiate between symptoms and its invisible problems. Also, a new knowledge for practitioners and researchers to apply in future $R \& D$. The framework is designed to show the horizontal and vertical relationship between the Tiers. Tier One is evidenced from financial report termed as "Major Signal of Weakness". Tier Two and Three are evidenced from unpublished organizational reports termed as Facts (Kader Ali et.al, 2014). The internal barriers faced by this company include high operational costs, tough negotiation process, ineffective promotion, working capital limitation, and weak talents and skill sets in foreign market. The external barriers include fierce competition from local and foreign SMEs, strict regulatory requirement and weak government support (Refer Figure 2).

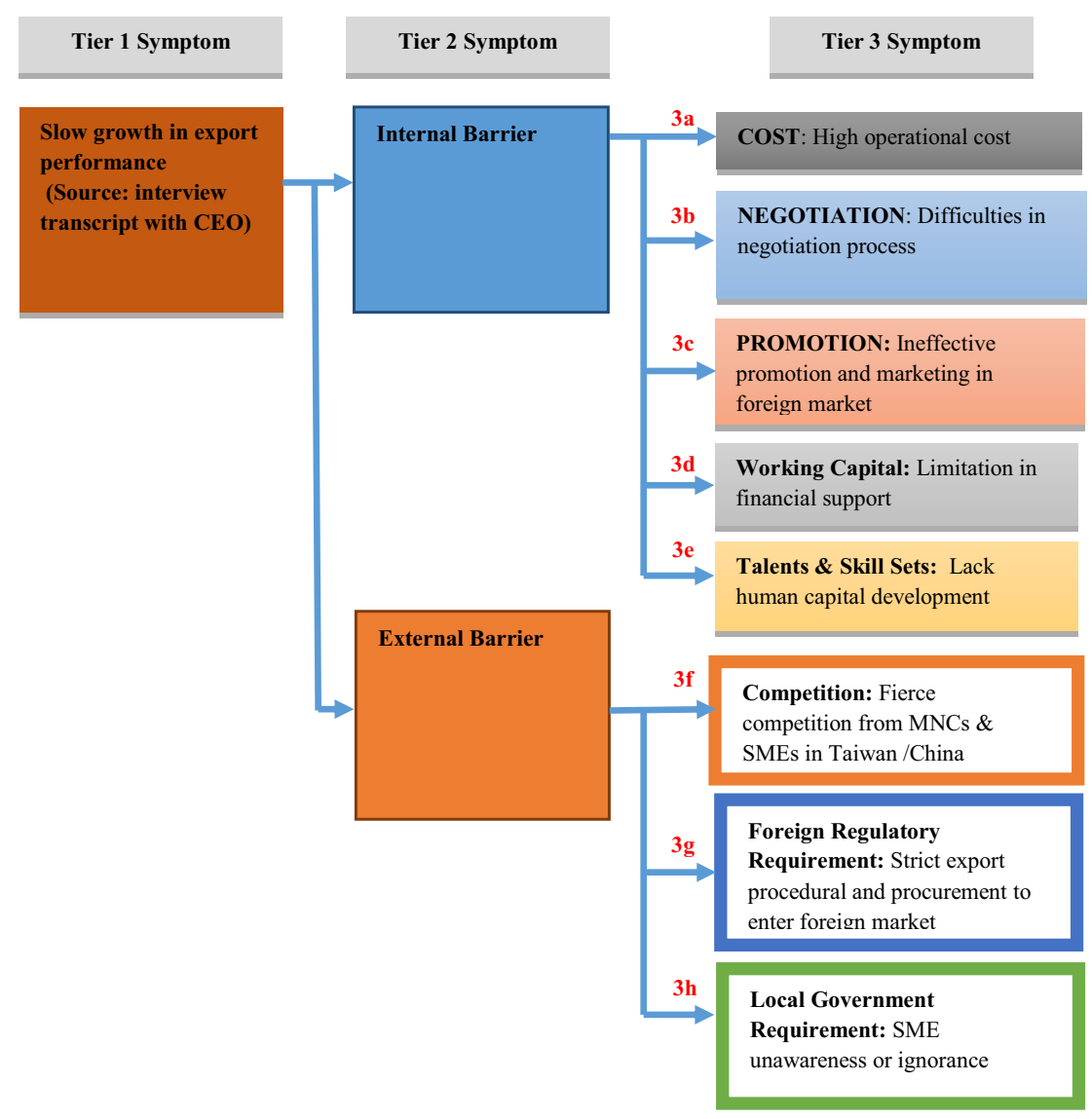

Figure 2: SVP Framework for SME LED Exports 
Internal Barrier - High Operational Costs (3a)

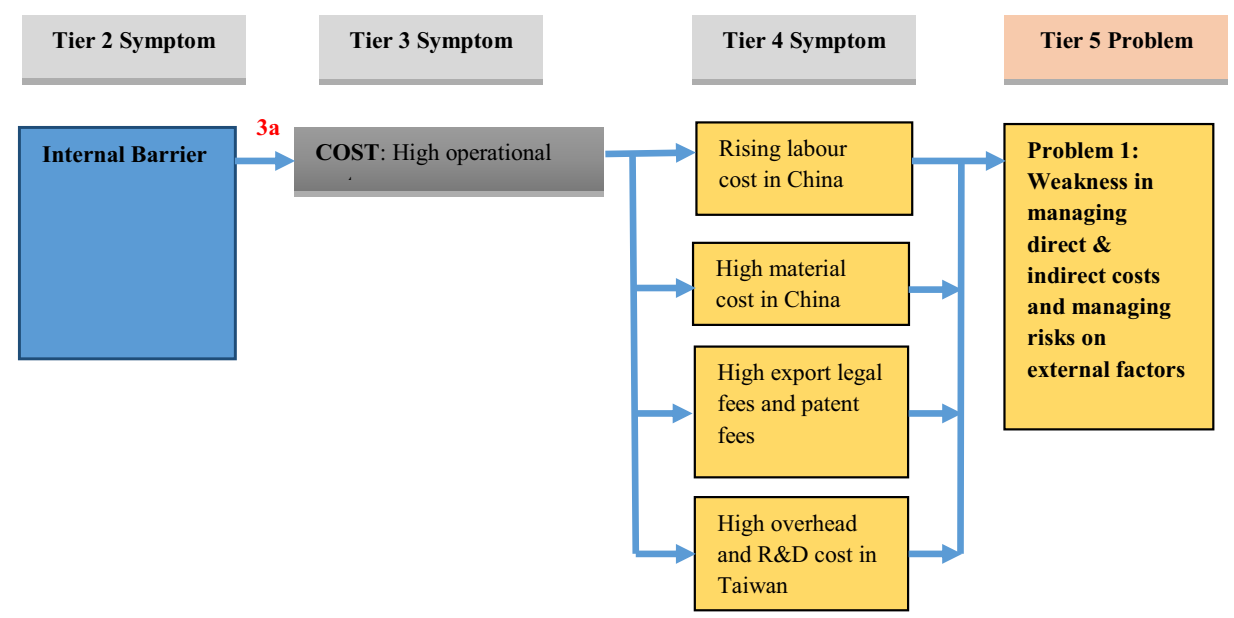

Figure 3: SVP Framework (3a) - High Operational Costs

Tier Four, also termed as Variables, (Kader Ali et.al, 2014) are frequently overlooked, unnoticed, hidden in financial costs. Whether the company engaged in direct or indirect exports, the rising labour and material costs in China, high agency, patent and legal fees, coupled with overhead and $\mathrm{R} \& \mathrm{D}$ costs are contributing to high product costs, making it less competitive in export price (The Company, 2015). External barrier on regulatory requirement pointed that since 2012 the U.S., EU, Japan and other countries have implemented new LED standards. On Feb. 1, 2013, the EU stipulated all imported luminaires (LED) must enhance Electric and Magnetic Force (EMF) tests (Lin, 2013). The external barrier affected internal barrier that causes product costs for exports to increase.

\section{Internal Barrier - Negotiation Difficulties (3b)}

Tier Four symptoms (refer Figure 4) indicate that often-sceptical buyers will force for price reduction. Buyer will evaluate based on quality, reliability, efficiency, and services of the product offered. Thus, higher LED standards by EU, US and others on EMF tests (Lin, 2013) and exclusive Liquid Immersed Thermal Management Solution (LITMS) technology increases quality and reliability, design and technology costs (The Company, 2015).

Effective Sept. 1, 2014, only LED lamps with high energy efficiency will be able to enter the EU market (Lin, 2013). Thus, product safety standard compliance requires the company to purchase better power management chips. Increase in price makes it difficult to negotiate as competitors are able to comply and offer better prices. Again external barrier influenced internal barrier in negotiation difficulties (The Company, 2015).

The company's difficulties are similar to other researchers' findings where SME tend to have limited resources, limited management experience, a limited degree of internationalization 
and high internal export barriers. They lack both the means and commitment to invest. (AduGyamfi \& Korneliussen, 2013). The risk increases negotiation difficulties.

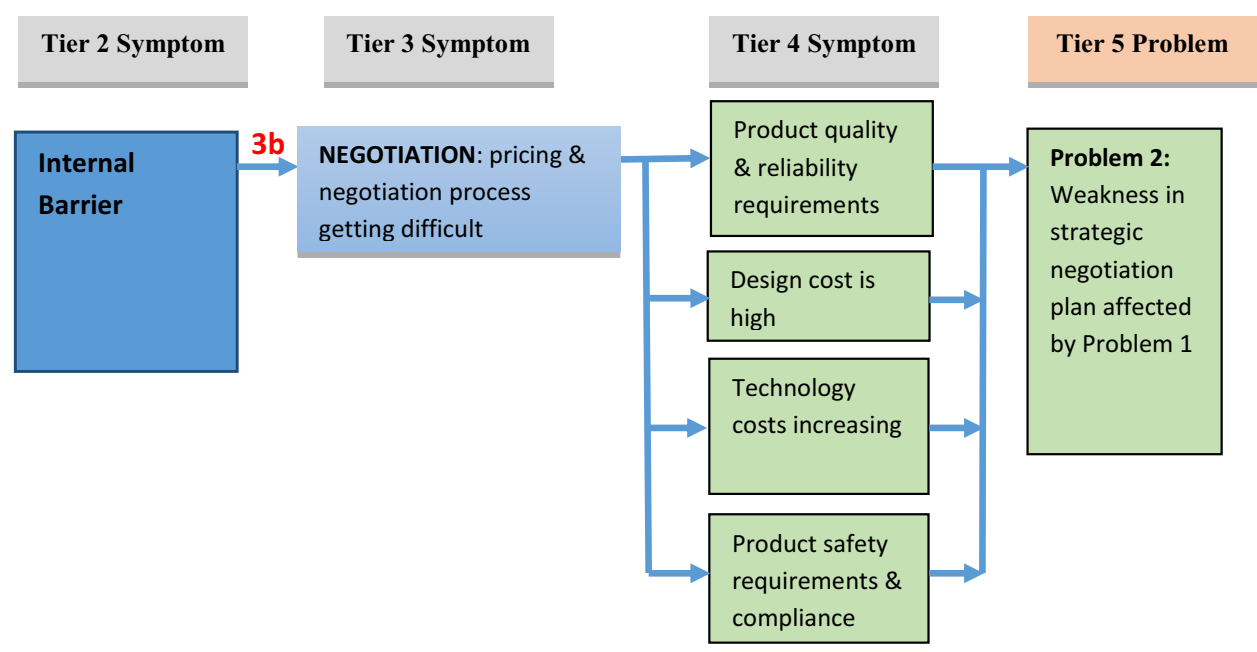

Figure 4: SVP Framework (3b) - Negotiation Difficulties

\section{Internal Barrier - Ineffective Promotion (3c)}

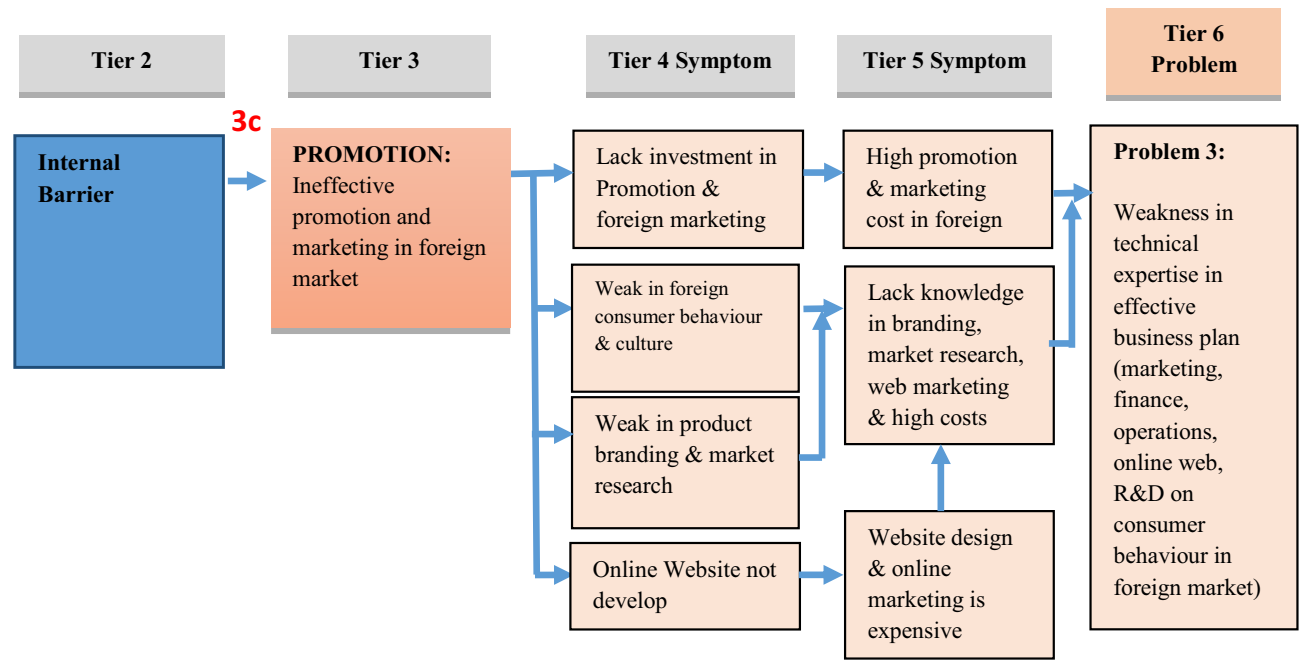

Figure 5: SVP Framework (3c) - Ineffective Promotion

Branding the products in the global market through promotional activities, market research on consumer behaviour in foreign market and investment in online marketing are neglected due to costs constraints. SMEs do not consider branding as their utmost strategy to compete 
globally. Limitation of capital investment hinders the efforts to invest in making products more attractive and well packaged, as well as, product innovation particularly for export market. According to the $\mathrm{CEO}$, different country needs to adapt to different marketing strategy. Thus, technical experts in marketing are costly and a constraint. Promotions are conducted via attending exhibitions and trade shows. Thus, competitiveness, high product branding cost, poor market research, poor web marketing, ineffective network communication, causing the company to lose out to competitors (The Company, 2015).

\section{Internal Barrier - Lack Working Capital (3d)}

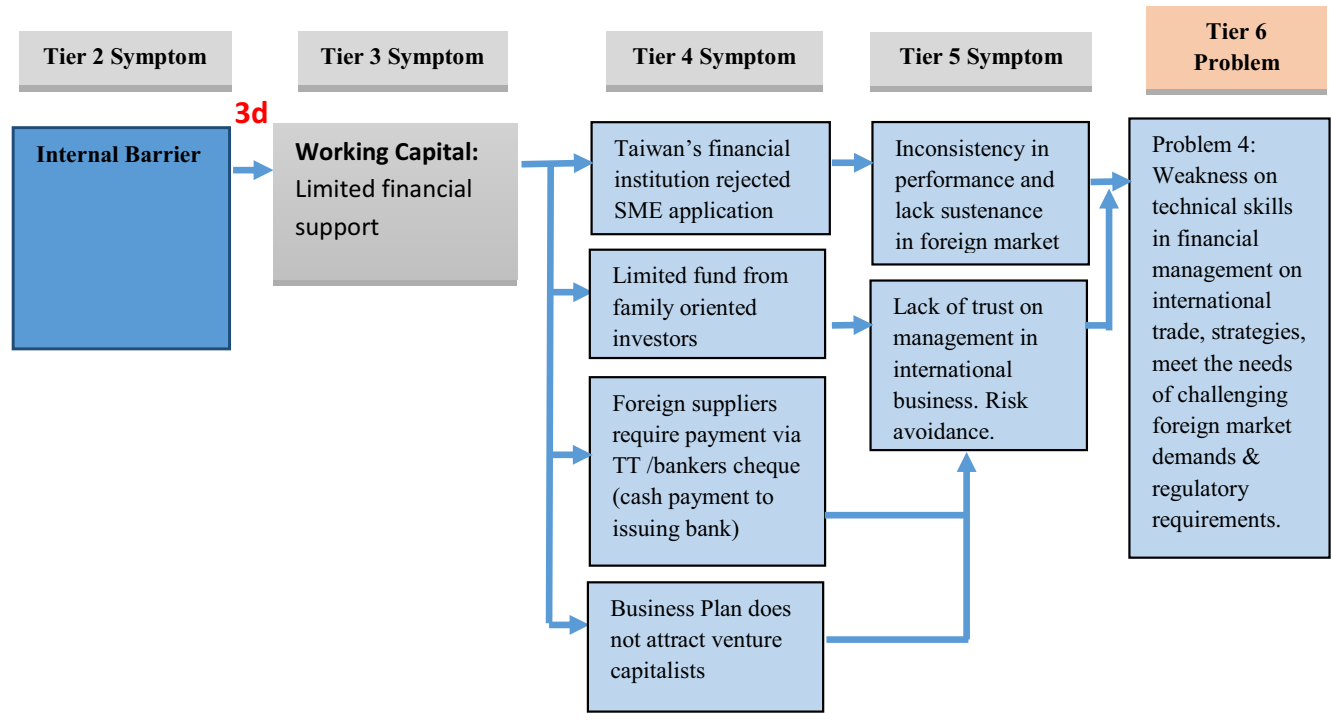

Figure 6: SVP Framework (3d) - Lack Working Capital

Financial barriers include high collateral requirements, bank charges, bank bureaucracy, banks ignoring or refusal of loan applications, processing and loan approvals takes too long, and high costs to prepare business plan. Investors within families do not have large capital investment and are risk avoiders. Venture capitalists prefer to partner with larger corporation with better probability of success rate. Foreign suppliers ensures that all payment are collected prior to delivery (The Company, 2015).

\section{Internal Barrier - Lack Talent \& Skill Sets (3e)}

According to the CEO, the company moved their manufacturing facility to mainland China, due to lack of human resources in Taiwan, who do not favour heat and high temperature environment, hampering the LED production. Training for the new workers is by on-the-job training learn by doing it and practices (The Company, 2015). Also, this finding was previously described by the author that lack of skilful workers will affect the firm productivity as well affects the export process (Pinho \&Martins, 2010). 
Furthermore, international negotiations require effective negotiation plan and strategies that the company is lacking. Lack in reliable market data, analysis, language barriers, follow-up, commitment, building relationships and trust, will affect export performance (The Company, 2015). This is related to Hashim (2012) findings that internationalization challenges faced by Malaysian SMEs can be grouped into five groups, namely, market knowledge, financial constraints, lack of infrastructure, technology and innovation, and human capital skillsets. $\mathrm{Hj}$ Idris, Abu Bakar \& Mohd Noor (2012) found that problems faced by entrepreneurs in Malaysia include lack of trustworthiness and commitment, lack of information technology, socialization problem, identification or selection of business networks and the role of agencies in supporting SMEs. Thus, investment in human capital development is crucial to improve export performance.

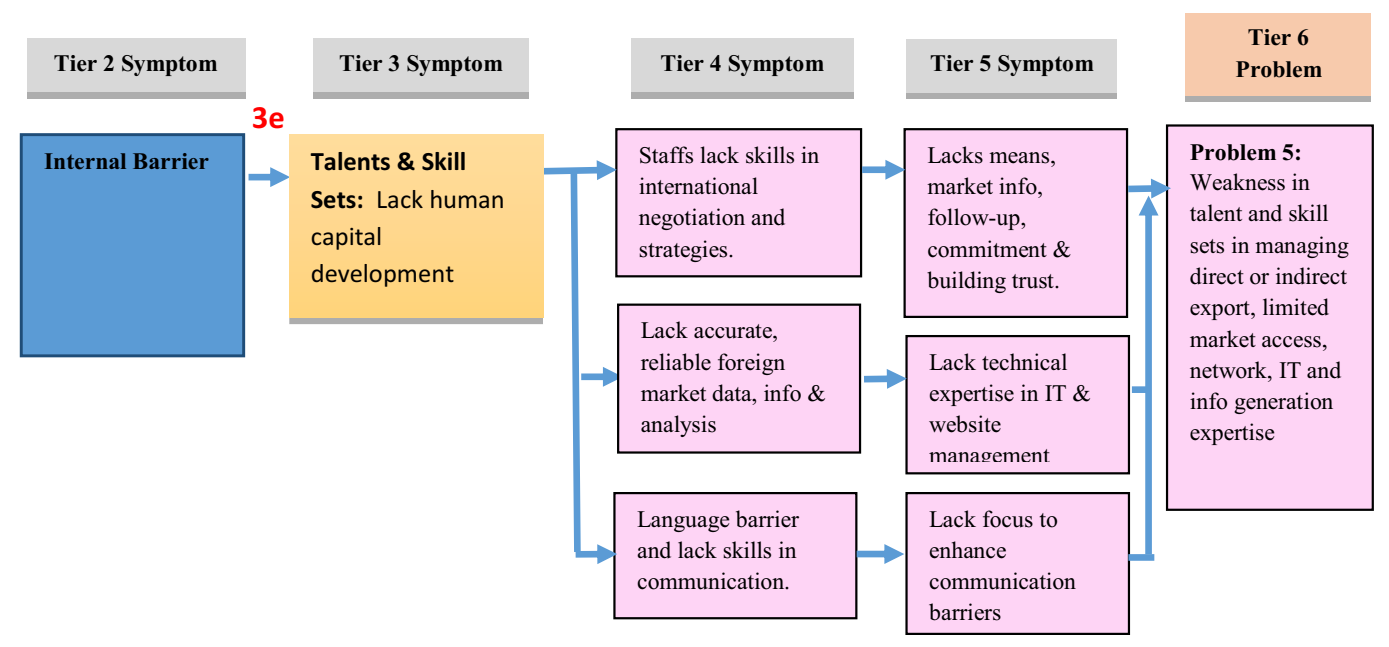

Figure 7: SVP Framework (3e) - Lack Talent \& Skill Sets

\section{External Barrier - Competitiveness (3f)}

According to the CEO, the company faces intensified competition due to increase demand from EU and US (The Company, 2015). This is similar to findings from Teoh \& Chong (2008) that states new emerging technologies in ICT, foreign exchange fluctuations, legal advice on new standard requirements on production process influenced the increasing factor costs, which affect the export competitiveness. SME facing recession, barrier from global sourcing, low productivity, lack of managerial capabilities, lack of financing, difficulty in accessing management and technology, heavy regulatory burden and others. (Refer Figure 8).

SMEs are facing the lack of knowledge on legal matters in relation to international business. Not many agencies that provide free advises to support SMEs pertaining to legal matters going abroad. Teoh \& Chong (2008) found the barriers of SMEs include lack of access to gain management experience and exposure in regards with international rules and regulations. Hence, SMEs may find access is restricted because of obsolete and inappropriate regulations (The Company, 2015). 
Decision process and R\&D landscape in SMEs with limited capital for business development of $\mathrm{R} \& \mathrm{D}$ are visible. There is lack of know-how about any latest and new emerging technologies including Internet in SMEs (Decker et al., 2006).

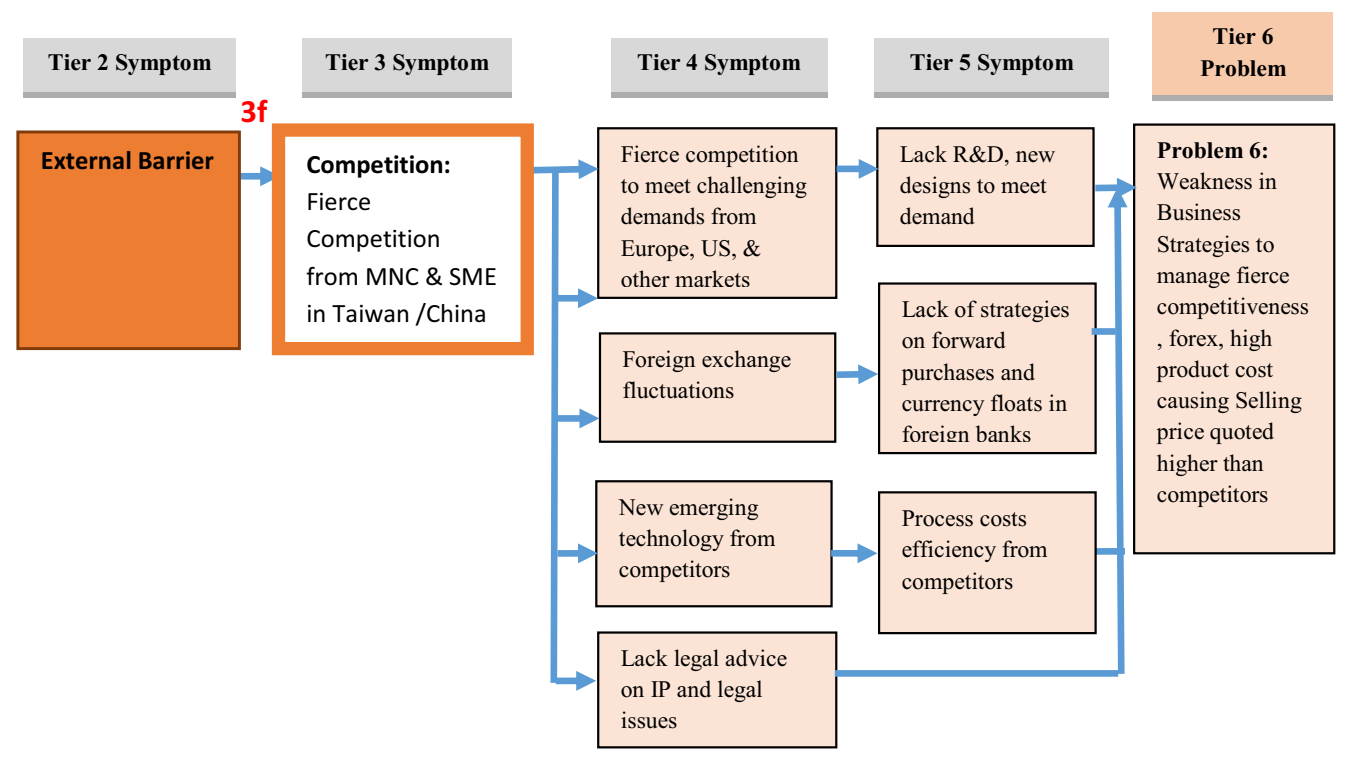

Figure 8: SVP Framework (3f) - Competitiveness

\section{External Barrier - Foreign Regulatory Compliance (3g)}

Since 2012 the U.S., EU, Japan and other countries are imposing new LED standards. On Feb. 1, 2013, the EU requires all imported LED must enhance Electric and Magnetic Force (EMF) tests (Lin, 2013), since the company's biggest client is in Germany. The EU has also issued a new LED energy efficiency regulation that require all LED exported products impose the use of powered management chips effective Sept. 1, 2013 and gradually raised yearly till Sept 1, 2016. (Lin, 2013). Trade barriers and technological barriers have brought new market changes recently, and triggered competition in China, Taiwan and Japan LED export companies, thus, increasing export risks (The Company, 2015). 


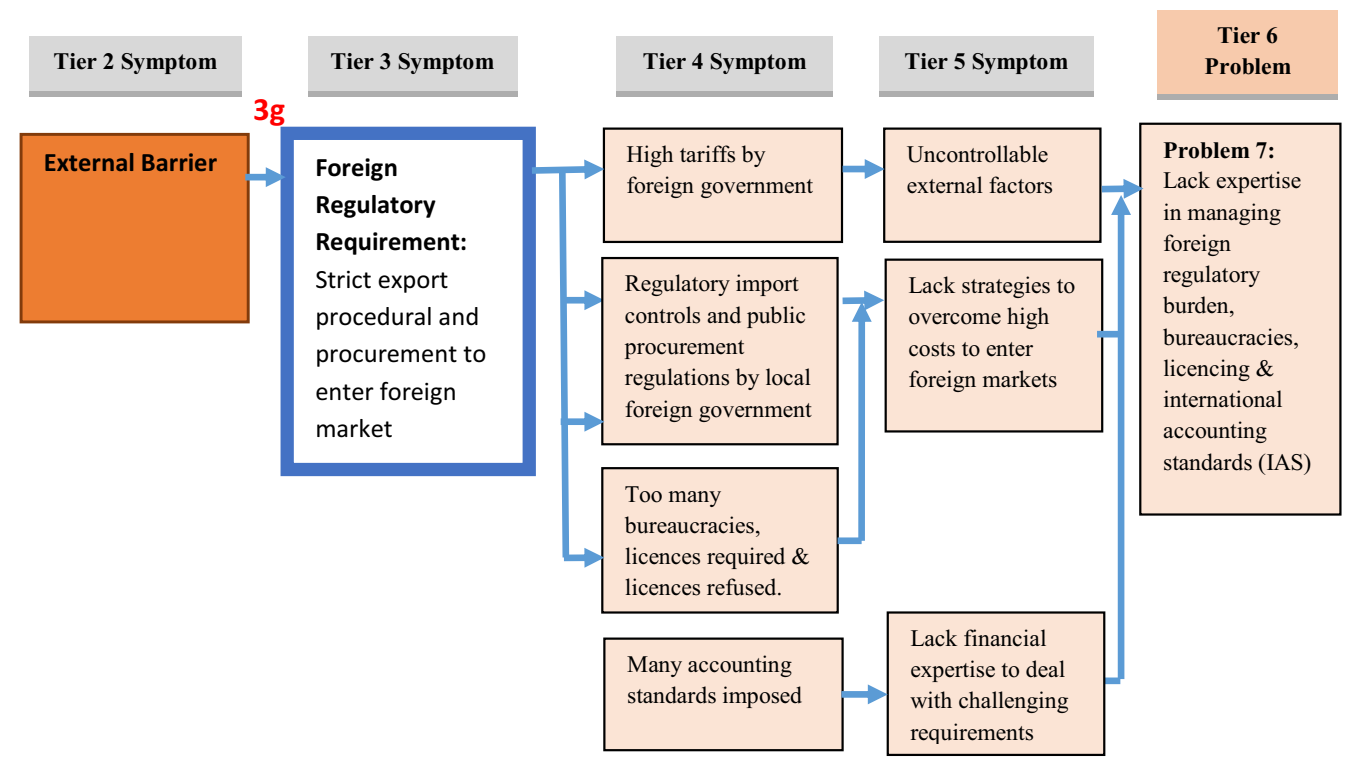

Figure 9: SVP Framework (3g) - Foreign Regulatory Compliance

The above results (Figure 9) in this study is consistent with other research findings where external export barriers include the imposition of tariff barriers and regulatory import controls by foreign governments, fierce competition, exchange rate fluctuations, limited foreign exchange for international trade, and cultural differences among others. (Tesfom and Clemens, 2006: Cavusgil and Zou, 1994, The Company, 2015).

Alam, Mohd Jani, Che Senik and Ahmad Domil (2011) found that Institutional barriers include bureaucracy, too many licenses required, complying to many accounting standards, licenses refused, public procurement regulations, lack of support services, constraints in obtaining Halal certification and lack of market information. The same is found in this case.

\section{External Barrier - Local Government Requirement (3h)}

Another external barrier known as Social Barriers include lack of state or government support, lack of support from business associations, lack of consultancy services, and lack of trust in society. The CEO states that the TAITRA or SMEA bureau serves more of providing up-to-date foreign market regulatory and legal compliance trade information. The cost of certifying a product bound for the European and US market is extremely high in Taiwan (The company, 2015).

The new EU LED lighting product regulation as an example, starting from the second phase of the new regulation after Sept. 1, 2014, only LED lamps with high energy efficiency will be able to enter the EU market. As a result, manufactured LED products or OEM products must purchase and use better power management chips (Lin, 2013). The EU standard is imposed by 
local government, increasing product costs and price competitiveness. In the other study, Teoh \& Chong (2008) found the barriers to entrepreneurship namely lack of access to formal business and social networks.

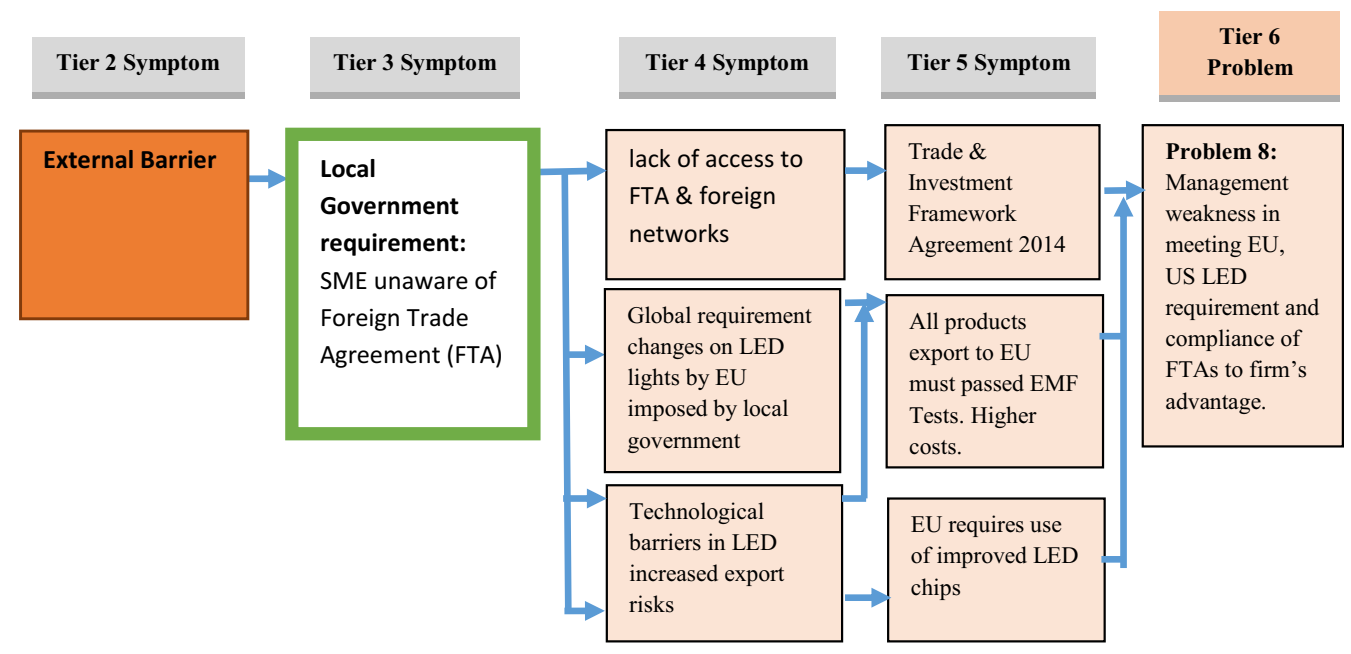

Figure 10: SVP Framework (3h) - Local Government Requirement

On other issue, Taiwan's upstream LED manufacturers enjoy a leading position in the global marketplace, while downstream firms account for less than 5 percent, because many of them are SME firms with diverse LED lighting applications (Lauly, 2015)

\section{RECOMMENDATION}

\section{Solution to Increased Export Costs (Tier 3a Symptom) \\ Problem 1: Weakness in managing direct $\&$ indirect costs and managing risks on external factors}

According to Fern'andez-Olmos \& D'1ez-Vial (2013), the use of intermediaries may enable a firm to perform certain export functions better or at a lower cost. Intermediaries have the know-how required to enter foreign markets ( $\mathrm{Li}, 2004)$. SME companies can also take advantage of the intermediaries' contacts, experience, and knowledge of foreign markets. However, using export intermediaries means incurring costs in terms of transaction costs and fees (Acs \& Terjesen, 2006). Another caution in exporting through an intermediary is the potential loss of control over the way in which the product is marketed and serviced (Blomstermo, Sharma, \& Sallis, 2006).

For managing risks on direct exports, Leonidou (2013) said at initiation stage, research of export markets, proper segmentation and targeting efforts, right partner selection, participating in trade exhibitions, first interaction with a foreign customer are important 
criteria to SME exporters. In development stage, the desire of the two parties to invest resources which cannot be used elsewhere, make use of each other's expertise, and increase the efficiency of business transactions are clearly stipulated in the contract terms.

\section{Solution to Negotiation Difficulties (Tier 3b Symptom)}

Problem 2: Weakness in strategic negotiation plan affected by Problem 1

According to Armstrong and Kotler (2009), firms may start with indirect exporting that involves less investment and less risk. Firms can acquire the services of export agencies or consultants to assist them in negotiation process. Firms may move to direct exporting negotiation process which involve greater risks with greater returns, only when they acquire sufficient talent and skill sets in complex negotiation process, including market segmentation and targeting efforts, selecting the right partner, sharing of business risks, sharing of regulatory requirements and compliances costs, aside from new technology enhancement and changes in direct costs as a result of price increase.

\section{Solution to Ineffective Promotion (Tier 3c Symptom)}

Problem 3: Weakness in technical expertise in effective business plan (marketing, finance, operations, online web, R\&D on consumer behaviour in foreign market)

Strategic business planning for exports evaluates critically the aspects of international marketing strategies, financial strategies in overcoming the domestic and export challenges, operational processes, regulatory compliances, and cost effectiveness. Also, it evaluates the effectiveness of online communications and online revenue generation, as well as, domestic and foreign consumer behaviour and related costs. According to Armstrong and Kotler (2009),

1. Firms need to set up a domestic-based export department or division that carries out planning, execution activities for exports and domestic regulatory compliances.

2. Set up overseas sales branch or partner with intermediaries that handles sales, promotion and distribution.

3. Send home-based sales personnel with technical expertise abroad to study consumer behaviour and find businesses.

4. Build networks with foreign-based distributors who buy and own the goods.

5. Build networks with foreign-based agents who finds customers on behalf of the firm.

Meanwhile, Strategic planning group in the firm ensures all the strategies are captured in the business plan, monitors the activities effectiveness through financial and non-financial performance evaluation for exports. Quarterly report indicators requires strategic improvements are made on all export activities to ensure sustenance of the export business activities.

Solution to Lack Working Capital (Tier 3d Symptom)

Problem 4: Weakness on technical skills in financial management on international trade, strategies, meet the needs of challenging foreign market demands \& regulatory 
Building trust with the banks begin with consistent positive domestic financial performance from small operations and continue the relationship with the selected banks. As the operations grow into export performance, banks are there earning their profits in supporting SMEs operations in which the bankers are familiar with.

As the business begins to grow, strategies on capital expansion for small firms to family oriented investors should begin when the business is doing well to gain the trust and risk averse. It is not effective when shares are offered to investors during hard times to cope with financial constraints period.

Foreign suppliers will continue to request COD payments despite excellent financial performance. Build a strong network in customer-supplier relationships, giving visibility of orders and consistent payment, social engagement with supplier partners, involving them in new project development, will open opportunities to supplier credit support internationally, through various financial terms. Thus, it is a long term planning in building the relationships.

Venture capitalists (VCs) prefer to deal with large corporation and strong SMEs to reduce the business risks. However, the success of the above three proposals will invite VCs to your firm, as they see great potential in the management team managing domestic and export markets.

\section{Solution to Lack Talent and Skill Sets (Tier 3e Symptom)}

Problem 5: Weakness in talent and skill sets in managing direct or indirect export, limited market access, network, IT and info generation expertise

Human capital development requires investment in training and development for all the areas mentioned in the above solutions for all the problems 1 to 8 specified. The related costs should be budgeted in the business planning for Human Capital Development.

\section{Solution to External Barrier on Fierce Competition (Tier 3f Symptom)}

Problem 6: Weakness in Business Strategies to manage fierce competitiveness, forex, high product cost causing Selling price quoted higher than competitors

Firms should be prepared with investment reserves, as well as, up-skilling of technical and operational skill sets on up to date new technology requirements as demanded from clients in importing countries (Refer solutions to Problem 4-5). Thus, it include compliance with regulatory requirements. (Refer solutions to Problem 7-8).

Meanwhile, continuous sustenance on customer satisfaction for services rendered helps to overcome the challenges of fierce completion. Kader Ali, et.al (2014), found that being reliable, competent, providing adequate customer support, efficient and effective in services rendered and empathetic with customer requirements are key towards building a long term relationship with customers. 
Taiwan has significantly improved the intellectual property rights (IP) regime. Taiwan authorities recently passed an improved trade secrets law which addresses an industry call to strengthen penalties for the theft of trade secrets (Department of Commerce, 2014).

Solution to External Barrier on Foreign Regulatory Requirement (Tier 3g Symptom) Problem 7: Lack expertise in managing foreign regulatory burden, bureaucracies, licencing $\&$ international accounting standards (IAS)

This firm manufacturing LED products should improve the establishment of core technologies, provide technical skills on export market laws, legal regulations, standards, and prepare in advance measures to cope with technology and trade issues. (Refer solutions to Problem 4). At the same time, the companies should also establish test laboratories approved by foreign countries to lower its testing fees and production costs. LED companies should also consider developing LED "blue ocean markets," such as Latin America, Africa, Middle East, Southeast Asia and other emerging markets (Lin, 2013).

\section{Solution to External Barrier on Local Government Requirement (Tier 3h Symptom) Problem 8: Management weakness in meeting EU, US LED requirement and compliance of FTAs to firm's firm's performance.}

Taiwan's local LED lighting manufacturers are urging the government to set stricter quality standards with energy-efficient LED lamps to prevent fierce price-cutting competition. In addition, the government requires LED project bidders to use components that are 99-percent locally made to make sure it will help Taiwan's green energy development and benefit Taiwanese LED makers (Lauly, 2015).

Meanwhile, Taiwan Lighting Fixture Export Association (TLFEA) has been promoting the inclusion of LED lighting products at World Trade Organization (WTO) Environmental Goods Agreement (EGA) negotiations in in Geneva from March 16-20, 2015, to promote the inclusion of LED lighting in the agreement. Taiwan's LED lighting products exported to China are subject to $5-20 \%$ tariffs, with a majority of product subject to $20 \%$ tariffs, as reported by China Times. If the proposal of including LED lighting in EGA is approved by WTO member states, Taiwan LED lighting products could be exempted from Chinese tariffs (Lin, 2015). Thus, the above examples indicated LED manufacturers continue to put pressure on the local government to set policies and regulatory requirements that support the development of local SMEs in Taiwan.

\section{CONCLUSION}

The SVP framework adapted from Kader Ali et al., (2014) in this study, reveals eight major problems that caused the slow growth in export performance (as indicated in Tier 1, Figure 2 a newly developed SVP Framework for SME LED Exports). The solutions proposed above were found to have inter-relationship among the problems. The solutions discovered during this study, are summarized in another newly developed framework called "House of 
Pillars for LED Exports" indicate potential high growth performance for LED industries, as depicted in Figure 11.

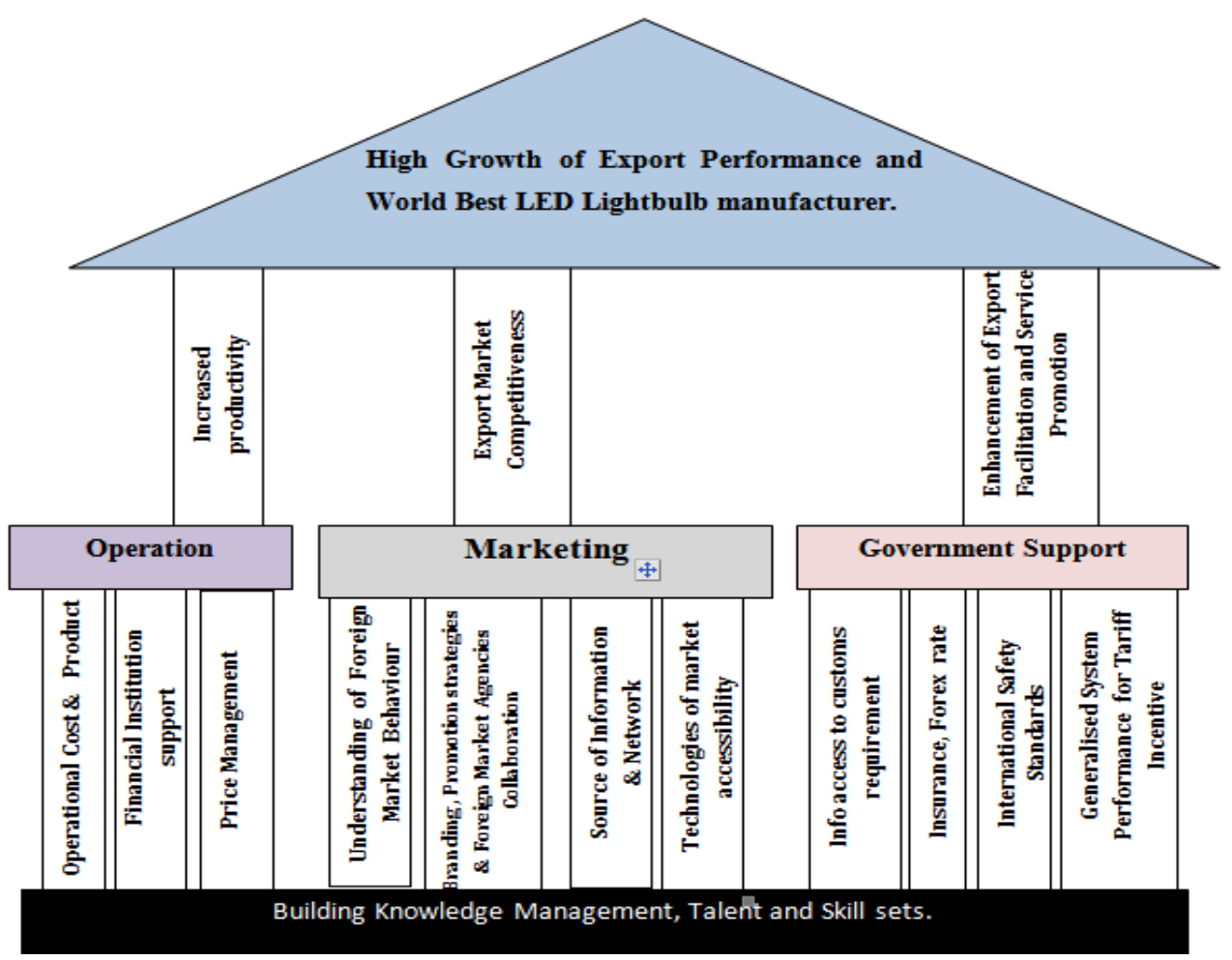

Figure 11: House of Pillars for LED Exports

The above figure shows the concrete foundation is necessary to build a strong and sustainable House of Pillars for LED Exports, and to achieve high export growth and performance. That is, to build knowledge management, talent and skill sets at all levels of LED development. The pillars are carefully constructed, to increase operational productivity, by managing effectively the product and total operational costs, support from financial institutions, and price management. To achieve reliable and effective export market competitiveness, firms should engage in foreign market behavioural research and analysis, incorporating the research results on branding and promotion strategies, collaborating with expert intermediaries and foreign market agencies, building database of information network, and enhancement new technologies and market accessibility. Enhancement of export facilitation and service promotion requires firms to provide active engagement in info access with governmental institutions on exports, managing insurance forex efficiently, comply to international safety requirements, and generalisation of system performance for tariff incentives.

In a brief, the impact of the above supply chain creates bigger revenue chain and bigger export market, thus, increasing the export performance, growth and yielding higher contributions to national GDP of Taiwan. 


\section{REFERENCES}

Department of Commerce (2014). Doing Business in Taiwan: 2014 Country Commercial Guide for U.S. Companies. Retrieved on 13 May 2015 from www.export.gov/taiwan/.../2014\%20TCG\%20Full\%20Final\%20Draft_07...

Lin, Judy (2013). Technical Barriers Raise Export Risks and Costs for Chinese LED Exporters. LED Inside, TrendForce Corp. September.4, 2013 - 14:56. Retrieved 13-5-2015 from http://www.ledinside.com/news/2013/9/technical_barriers_raise_export_risks_and_costs_for_ chinese_led_exporters

Lin, Judy (2015). Taiwan LED Industry Advocate Lifting LED Lighting Tariffs at WTO Talks. LED Inside, TrendForce Corp. April 20, 2015 Retrieved 15-5-2015 from http://www.ledinside.com/news/2015/4/taiwan_led_industry_advocates_lifting_led_lighting_t ariffs_at_wto_talks

Kader ali, Noor N., Mohd Isa, Salmi., Mohaidin, Zurina., and Goh, Yen Nee (2014). Level of Service Quality on Customer Satisfaction for Tenaga Nasional Berhad, Penang (Unpublished contract research report, 30 June 2014).

Kader Ali, Noor N., Wilson, P. and Mohammad, I.Y. (2014). Symptoms Versus Problems Framework (SVP): An Innovative Root Cause Analysis Tool. International Journal of Organizational Innovation, special issue, pp.66-76.

Kader Ali, Noor N., Wilson, Priyah and Ismeth, Yazmin (2015). Symptoms Versus Problems (SVP) Analysis On Job Dissatisfaction And Managing Employee Turnover: A Case Study In Malaysia. International Journal of Economics, Commerce and Management United Kingdom.Vol. III, Issue 4, April 2015. Licensed under Creative Common. Page 1-29, http://ijecm.co.uk/ ISSN 23480386.

Lauly, Li (2015). LED Group Pushes Government To Set Higher Standards For Lighting Project. Taipei Times. Sat, Jan 24, 2015 - Page 13. Retrieved 15 May, 2015 from http://www.taipeitimes.com/News/biz/archives/2015/01/24/2003609935

MATRADE.(2003). How to be an Exporter $Q \& A$ on Exporting. $2^{\text {nd }}$ edition. MATRADE Business Handbook.

The Company (2015). Interview Transcripts. The Company Lighting Corporation, Taiwan. Appendix A. MBA Project Management Thesis 2015, Graduate School of Business, Universiti Sains Malaysia. 